ISSN: 2664-8148 (Online)
Liberal Arts and Social Sciences
International Journal (LASSIJ)
https:// doi.org/10.47264/idea.lassij/ 1.2.1
Rol. 3, No. 1, (January-June) 2019, 1-8
https://www.ideapublishers.org/lassij

\title{
Women's Political Empowerment through Local Government in the Patriarchal Society of Pakistan
}

\author{
Niaz Ahmad ${ }^{1}$ and Abida Bano*2
}

1. Department of Sociology, Faculty of Social Sciences, University of Peshawar, Peshawar Pakistan.

2. Institute of Peace and Conflict Studies, Faculty of Social Sciences, University of Peshawar, Pakistan

\begin{abstract}
The democratic local government empowers community members to decide their destiny. However, it bears different meanings for different people in different socio-cultural settings. This study assesses the intended outcome of the local government system, revived by General Pervez Musharraf's regime in Pakistan since 2001 regarding women's political empowerment. In the Devolution Plan 2001, the gender quotas of $33 \%$ have been reserved for women in all the three tiers of local government at the district level. However, the existing informal institutional forces like socio-cultural and religious practices did not let women to fully participate and achieve the desired political status. Local women's representatives have not been able to participate meaningfully in the policymaking at the local level. Therefore, this study suggests revising the design of the local government with a focus on eligibility criteria for the candidates. Moreover, to ensure the political empowerment of women, policymakers should focus on other alternatives like women education, political awareness, and monitoring by the civil society and media.
\end{abstract}

Keywords: Local government, gender quotas, women representatives, women empowerment

\section{Introduction}

Democratic decentralization has been in practice successfully in various countries such as United Kingdom, Sweden, and several Latin American countries, among others. Democratic local governance, an outcome of democratic decentralization, is visualized as the most suited vehicle to enhance political participation of the traditionally excluded groups (women, minorities) in the decision-making processes and to achieve the developmental goals (see Crook \& Manor 1998; Badshah, Rehman, \& Muhammad, 2018). Being participatory, local government brings governance closer to local people. Theoretically, local government ensures an exact representation of marginalized sections of the society (workers, peasants, women, and other constitutional minorities). Local councils, composed of elected representatives, are empowered to make decisions on behalf of their respective constituencies.

Looking from a gender perspective, these local government institutions are not equitable. Since the prevailing socio-cultural practices and the varying degrees of economic statuses hinder women from playing an active role in the decision-making processes in the local government. 
Consequently, women, constituting about half of the population, are under-represented in a substantial way. Moreover, Staudt (1991) holds that development policies are made behind the closed doors in a non-transparent political structure. Therefore, in such an environment the absence of women questions their interests. Noticing the gap Fourth World Conference on Women in Beijing 1995 considered women's representation as one of its core areas of interest. Consequently, many developing countries either introduced gender quotas or increased reserved seats for women in decision making.

To make women's voices heard in policy formulation, the role of civil society is also crucial. Several women's groups and other organizations working for women's rights in different regions have been struggling for the inclusion of women in decision-making. The studies conducted on the effectiveness of gender quotas also show that woman should and could represent women's interests in a better way (Young, 2000; Shah, Rehman, Ali, \& Ashfaq, 2018). Scholars also argue that women's experiences are different from men, and therefore, men cannot represent women's problems (Osborn, 2012; Piscopo, 2012; Young, 2017). However, various kinds of socio-cultural hindrances that stop women's entry into the places where policies are formulated. Goetz (1998) argues that some electoral changes are needed to eliminate the barriers that are responsible for women's exclusion from the decision-making processes. Several initiatives have been taken in many countries; among these changes gender quotas or seat reservation system is considered an effective way for women to enter the decision-making process. This system is currently in practice in more than 84 countries since 2006 (Ahmad, Bano, Rehman, 2017; Foggo, 2012).

Generally, the gender quotas are of three main types, i.e., voluntary party quotas, compulsory party quotas, and reserved seats, whereas the focus of this paper is on reserved seats. Indeed, quotas or reserved seats have proved to be a useful strategy for increasing the numerical representation of women in local legislatures. However, questions arise that how women representatives cope with patriarchy and participate in political processes substantively? Whether the elected women exercise powers assigned to them by democratic decentralisation and how? Moreover, how these women councillors interact with their male colleagues? These questions are concerned with the post-election scenario; hence, this paper aims to examine the experiences of the elected women in the local government in the Pakistani context. This paper is divided into five main sections; the first section introduces the topic of study and entails the research question. The second section locates the topic in broader as well as in the Pakistani perspective. The third section explains research methodology as well as the material used in this study. The fourth section contains results and discussion, and the last section composes suggestions and recommendations.

\section{Literature Review}

\subsection{Gender Electoral Quotas vs. Patriarchy}

The electoral gender quotas are adopted by different countries to ensure women's representation in decision-making processes. The main objective behind the practice is to increase the descriptive and substantive representation of women in legislative bodies. It is assumed that an increase in the numerical representation of women would consequently lead to women's political empowerment (Dahlerup, 2005). Different scholars use the term 'empowerment' in various ways, however, in this paper it refers to the actions and decisions of the elected women representatives in a local political arena in a patriarchal society such as 
Pakistan. In other words, women empowerment means the complete realisation of the absence of the influence of patriarchy on the elected women's representatives while exercising their powers assigned to them by the institution of the local, provincial, and national government (see Shafiq \& Rehman, 2018).

Some of the scholars have extensively studied the effectiveness of electoral gender quotas from various perspectives (Rai, 1999; Hust, 2002; Dahlerup, 2005; Tripp, 2008). Dahlerup and Freidenvall (2005) identify two different tracks to increase women's representation in legislative bodies. First one is called an incremental track, which is a long-time process of gradual increase in women's representation. It is argued that in this process, political parties endeavour to recruit and equip women enough to enter the male-dominated political sphere since they will be able to decide on behalf of women's interests. The other is called a fast track to increase women's representation through electoral engineering like the introduction of gender electoral quota or seats reserved for women in legislative bodies. About the later track Dahlerup (2005) asserted that the application of gender quota alone is not supportive enough to achieve the goal of women political mainstreaming in terms of their representation rather it may play a causative role in generating proxies (Mohantay, 2003; Rai, 2003; Sharma, 2003). Dahlerup (2005) concluded that electoral gender quota alone is not enough to erase all of the hindrances faced by women in pre-election (decision to run in election and campaigning) and post-election (exercising their power as an elected representative and performing the job). However, if implemented carefully and properly its efficiency cannot be ignored in promoting women's interests. Moreover, she suggests further qualitative studies to evaluate the impact of electoral gender quotas (see, Bilal \& Ahmad, 2018).

Rai (2003), in her study, links women's political representation with their empowerment. The empowerment has been taken as a participatory and democratic process that provides an opportunity for the people to formulate policies, which affect their lives. She shows a correlation between increased women's representation in local government (through gender quota) and women's empowerment in the Indian context. According to the writer in India, the Bill reserving 33 percent seats for women in local government was passed without any opposition from any political party, but the legislation was discouraged for parliament level. The reason behind was that local government had not been given any vital role in Indian politics while political parties did not approve the increased representation of women in parliament. This high gender-biased approach toward women's political representation of women is the hallmark of most South Asian societies including Pakistan. However, during Musharraf ${ }^{1}$ regime, reserved seats for women were increased at local, provincial, and national levels (see Naazer, Mahmood, \& Ashfaq, 2017).

Furthermore, Hust (2002) empirically tested the impact of electoral gender quota in local government in India in terms of the presence of women in local councils and the way these elected women exercise power. The findings of the study show that women are provided with a very restricted public space. From the very start, women seek permission in anticipation from their husbands/fathers to run in the local government elections. Another key point about community attitude towards quota legislation is that most of the villagers were not in favour of this legislation. They were of the view that women are not fit for a political role. In explaining the ways these elected women exercise power, Hust argues that they were at odds. Since they lacked knowledge regarding local politics. Most of the women's representatives were not interested in politics and politics was considered an area of men. 


\subsection{The Quandary of Gender Quotas in Local Government in Pakistan}

The time Pakistan emerged as an independent state in 1947, only a few districts of Punjab province with well-established local government units, came in her part (Rizvi, 1976). Nevertheless, these local government units were not representative of the local people instead dominated by bureaucracy (Quddus, 1981). After independence, local government was paid no heed. However, in the 1960s during General Ayub's ${ }^{2}$ regime, local government was introduced formally and systematically. The local government institutions revitalized and introduced under the name of Basic Democracies Order (henceforth BDO). Basic Democracies was a welcome initiative on the part of President Ayub Khan's regime for the empowerment of the local elite and transfer powers to the masses. However, this initiative entailed serious administrative issues that hindered the local people's exercise of powers. Though space was created for local representatives, but they were under the control of central bureaucracy at the district level (Khan, Khan \& Rehman, 2017).

According to Gauhar (1996), this system was used as a safety valve for Ayub's regime. It remained only in papers after 1969 and was not functional. For the second time, local government was revived by General Zia-Ul-Haq in 1979 under Local Government Ordinances (LGOs). However, it was not much different in nature and efficiency from BDO of Ayub's regime (Cheema, Khwaja, \& Qadir, 2005). Elections under local government ordinances were held on non-party basis that cut off linkages between local and provincial level leadership. Lack of such vertical ties between lower and upper tiers created tensions between the two levels of leadership (Wilder, 1999; Khan \& Rehman, 2018). The latest local government initiative was taken in 2000 under the "Devolution Plan 2000". A commission called "National Reconstruction Bureau (NRB)" was formed to prepare a draft for the devolution plan including decentralisation of administrative and professional functions, citizen's empowerment, and distribution of financial resources (Khan, 2004). The Devolution of Power Plan-2000 introduced 33 percent seats reserved for women in all the three tiers of local government. Under the plan first local government elections were held in 2001 which brought 126,462 new Union Councillors out of which 17 percent were women (Charlton et al., 2003).

\section{Research Methods}

In Khyber Pakhtunkhwa, ${ }^{3}$ patriarchal practices provide a callous environment for women's political role. Besides patriarchy, other factors like low levels of female education, the practice of purdah ${ }^{4}$ and no share in the economic sphere are cogent challenges to women's empowerment in Pakhtun society of Khyber Pakhtunkhwa, Pakistan. Therefore, selection of the said province as a study area will bring robustness and credibility to the findings of the study (Hust, 2002). Pakhtun culture is dominant in Khyber Pakhtunkhwa which restrict women to their homes and household chores. The division of gender roles is followed in rural areas. Men are the primary breadwinners, and decision-makers in all walks of life. The available resources fell short to cover whole of the province. Therefore, Karak was selected as a representative district bearing almost all the prominent characteristics of the Pakhtun society of the province. A total of 25 respondents were selected categorically, i.e., elected women councillors, $\mathrm{Nazim}^{5} /$ naib $^{6}$ nazims, and common men. Ten (10) respondents out of each category were selected purposively. The study uses in-depth individual interviews as the primary tool of data collection. Additionally, to grasp more in-depth realities of the context, participant observation was engaged for validity purposes. 


\section{Discussion and Findings}

This section of the paper contains a thematic discussion of the main findings.

\subsection{Social Status of Women}

Most of the respondents noted that socially women are identified with a man in the Pakhtun society. Hence, they do not bear an individual identity in the male dominated society of Khyber Pakhtunkhwa. In some instances, they are considered as the property of men. Mostly, they have no say in decision directly affecting their lives. They are under the heavyweight of patriarchy and have been crushed to the extent that any law and other affirmative actions cannot emancipate them. One of the respondents from ordinary people noted, "Here, women are not more than pets, and we keep them restricted to the walls of our houses. Women are not fit for taking part in the public sphere." Similarly, one of the lady councillors when asked about her decision to stand for election, said, "Oh my boy, we are like animals, and we are pulled by our owners (men) wherever they want."

Furthermore, most of the elected women were unaware of their responsibilities, and their male family head performed their public duties. One striking finding was that the majority of the women district councillors were above fifty years of age and illiterate as the entry of a young woman into the public sphere is considered dishonourable and even scandalous. Therefore, most of the people (men) did not let their young and educated women enter the local political arena. In such dissimilitude circumstances, electoral gender quota falls short of paving the way for gender mainstreaming in politics.

\subsection{Lady Councillors' Niche in the Local Government Office}

According to most of the respondents of the study, there is a stark distinction between the in and out the social environment of the local government office. The social environment outside the local government office is entirely against the notion of gender parity. In Pakhtun culture, it is very contemptible for men in the rural context whose women perform public duties outside the walls of their homes. So, gender inequality is a norm in Pahktun society, and this norm profoundly affects local government. One of the lady councillors said, "a corner was allocated for use in a district assembly hall while our men discussed issues with our male colleagues on our behalf." Due to prevailing patriarchal practices inside the local government offices, women were restricted to a small corner and were unable to move and speak freely with other (male) local government officials.

\subsection{Exclusion from Political Discussions and Decision Making}

A total of 19 respondents out of 25 stated that women councillors are not consulted in political discussions and decision making in the local councils. Among the stated reasons, purdah (segregation), lack of education of women councillors, and no previous political experience were the main ones. The respondents noted that women councillors could not effectively participate in political processes because it was not possible for them to interact with their male counterparts freely due to cultural barriers. However, women councillor's presence in the local councils in name and numbers only is also a good omen for many poor women in society of Khyber Pakhtunkhwa, women councillors noted. 
In the light of the above results, this paper argues that the introduction of gender quota in local government is beneficial only in enhancing the numerical representation of women and may be considered as a "fast track" in Dahlerup's (2005) words or short-term remedy. However, to achieve women's (political) empowerment in a real sense, other factors should be addressed appropriately. Among these, women's education and economic position are crucial. Zetterberg (2009) also argues that gender quota proves little positive impact on women's political empowerment in Latin America because the informal practices provide a challenge to the intended outcome of gender quotas. Similarly, Paxton and Hugh (2007) suggest that for the enhancement of women's political representation it is imperative to uplift their position in the social structure.

\section{Conclusion}

Considering the above discussion, it is concluded that local government empowers the masses and transfers powers to the people at the bottom. That is why it is a welcome step on the part of the government. Regarding women's empowerment in Pakistan, local government in Pakistan played a putative role by bringing women to local councils. Women suppression was socially and culturally embedded and were out of the reach of formal institutions like local government to rescue them. Although Devolution Plan 2001 focused on women's political empowerment only, however, it could not succeed in achieving this aim. Main reasons behind the failure were the practice of informal socio-cultural institutions, i.e., patriarchy, purdah, ghairat, among others that barred women from taking an active role in political sphere. Following are the key suggestions of the study:

a. The study suggests that there should be minimum education mandatory for local councillors.

b. The government should regularly arrange capacity building workshops for women councillors.

c. The attendance of the local councils' meetings should be mandatory for the members of the councils.

\section{References}

Ahmad, N., Bano, A., \& Rehman, A. U. (2017). Impact of the informal institutional forces on the local government elections in Pakistan. Liberal Arts and Social Sciences International Journal (LASSIJ), $\quad 1(1), \quad 62-70$. https://doi.org/10.47264/idea.lassij/1.1.7

Badshah, L., Rehman, A. U. \& Muhammad, N. (2018). Political determinants of voting behaviour in Khyber Pakhtunkhwa. Liberal Arts and Social Sciences International Journal (LASSIJ), 2(1), 1-10. https://doi.org/10.47264/idea.lassij/2.1.1

Bilal, M. \& Ahmad, A. (2018). Political reforms and women political participation in Khyber Pakhtunkhwa. Liberal Arts and Social Sciences International Journal (LASSIJ), 2(2), 67-79. https://doi.org/10.47264/idea.lassij/2.2.8

Charlton, J., Cyan, M., Hasnain, Z., Manning, N., Porter, D., \& Sharif, H., (2003). Devolved service delivery study. World Bank, Asian Development Bank and the Department for International Development.

Cheema, A., Khwaja, A. I., \& Qadir, A. (2005). Decentralization in Pakistan: Context, content, and causes. KSG Faculty Research Working Paper Series. John F. Kennedy School 
of Government of Harvard University.

https://www.hks.harvard.edu/publications/decentralization-pakistan-contextcontent-and-causes

Crook, R. C., \& Manor, J., (1998). Democracy and decentralisation in South Asia and West Africa: Participation, accountability, and performance. Cambridge: Cambridge University Press.

Dahlerup, D., \& Lenita, F. (2005). Quotas as a 'fast track' to equal representation for women: Why Scandinavia is no longer the model. International Feminist Journal of Politics, 7(1), 26-48. https://giwps.georgetown.edu/resource/quotas-as-a-fast-track-to-equalrepresentation-for-women/

Foggo, L. (2012). Strategies to increase women's representation in Parliament in small states. $58^{\text {th }}$ Commonwealth Parliamentary Conference, Colombo, Sri Lanka.

Gauhar, A. (1996). Ayub Khan: Pakistan's first military ruler. Lahore: Sang-e-Meel Publication.

Goetz, A. M. (1998). Women in politics and gender equity in policy: South Africa and Uganda. Review of African Political Economy, 25(7), 241-262. https://doi.org/10.1080/03056249808704312

Hust, E. (2002). Political representation and empowerment: Women in the institutions of local government in Oriss a after the $73^{\text {rd }}$ amendment to the Indian Constitution. Heidelberg Papers in South Asian Comparative Politics: Working Paper No. 6, August.

Khan, A., Khan, T. M. \& Rehman, A. U. (2017). Government-opposition relations amidst the provincial autonomy during Bhutto regime. Journal of the Research Society of Pakistan, 54(2), 41-52. http://pu.edu.pk/images/journal/history/PDF-FILES/04Paper_54_2_17.pdf

Khan, N. U., \& Rehman, A. U. (2018). National character and leadership in Pakistan: Challenges and response. Pakistan Journal of Criminology, 10(2), 57-71. http://www.pjcriminology.com/wp-content/uploads/2019/01/4.pdf

Khan, S. (2004). Local government and participatory rural development (Ph.D. Thesis) Department of Public Administration, Gomal University, Dera Ismail Khan. pp. 157182. http://prr.hec.gov.pk/jspui/handle/123456789/3125

Mansbridge, J. (1999). Should blacks represent blacks and women represent women? A Contingent "yes." The Journal of Politics, 61(3), 628-657. https://wappp.hks.harvard.edu/files/wappp/files/should_blacks_represent_blacks_an d_women_represent_women_a_contingent_yes 1.pdf

Mohanty, C. T. (2003). Feminism without borders: Decolonizing theory, practicing solidarity. Durham: Duke University Press.

Osborn, T. L. (2012). How women represent women: Political parties, gender, and representation in the state legislatures. Oxford: Oxford University Press.

Paxton, P., \& Hughes, M. M. (2007). Women, politics, and power: A global perspective. Thousand Oaks, CA: Pine Forge Press.

Piscopo, J. M. (2011). Do women represent women? Gender and policy in Argentina and Mexico. Doctoral dissertation, University of California, San Diego.

Quddus, M. A. (1981). Pakistan: A case study of a plural society. South Asia Books.

Rai, S. M., (1999). Democratic institutions, political representation and women's political empowerment: The quota debate in India. In Democratization, 6(3), pp. 84-99. https://warwick.ac.uk/fac/soc/pais/people/rai/publications/democraticinstitutions/

Rai, S. M. (2003). Institutional mechanisms for the advancement of women: mainstreaming gender, democratizing the state. In Mainstreaming Gender, Democratizing the State: 
Institutional Mechanisms for the Advancement of Women, 15-39. Manchester University Press.

Rizvi, S. A. (1976). Changing patterns of local government in Pakistan. Karachi: Pakistan Historical Society.

Shafiq, S., \& Rehman, A. U. (2018). Land, conflict and traditional institutions in North-West Pakistan: An appraisal of Hazarkhwani, Peshawar. Journal of the Punjab University Historical Society, 31(1), 335-346. http://pu.edu.pk/images/journal/HistoryPStudies/PDF_Files/22_V-31-No1Jan18.pdf

Sharma, A. (2003). Women's political participation and leadership in the governance of municipal institutions in an Indian States. Paper presented at the conference; Women and Politics in Asia, Halmstad, Sweden, June 6-7.

Staudt, K. (1991). Managing development. London: Sage Publishers.

Tripp, A. M. (2008). The global impact of quotas on the fast track to increased female legislative representation. Comparative Political Studies, 41(3), 338-361. https://doi.org/10.1177\%2F0010414006297342

Wilder, A. R. (1999). The Pakistani voter: Electoral politics and voting behaviour in Punjab. Karachi: Oxford University Press.

Young, I. M. (2017). Gender as seriality: Thinking about women as a social collective. In Gender and Justice (pp. 3-28). Routledge.

Zetterberg, P. (2009). Do gender quotas foster women's political engagement? Lessons from Latin America. Political Research Quarterly 62(4), 715-730. https://journals.sagepub.com/doi/10.1177/1065912908322411

\section{Notes:}

\footnotetext{
${ }^{1}$ General Pervez Musharaf was Chief of the Army Staff of Pakistan and ousted the democratic government of Pakistan Muslim League led by Mian Muhammad Nawaz Sharif in 1999.

${ }^{2}$ General Ayub Khan was the first native Commander-in-Chief of Pakistan army. He was declared martial law administrator in 1958 when Iskander Mirza the then President of Pakistan declared martial law in Pakistan.

${ }^{3}$ One of the provinces in Pakistan with Pakhtun ethnic majority, which is bordered with Afghanistan.

${ }^{4}$ It is a religious and socio-cultural practice of veiling of the whole body by adult women. However, in Pakhtun culture Purdah refers to strict segregation between men and women spaces.

${ }^{5}$ An elected head of a union council.

${ }^{6}$ Second to the head or chief of an institution, department etc.
} 